\title{
GROWTH ANALYSIS OF CHICKPEA (Cicer arietinum L.)
}

\author{
S.S.S. NOGUEIRA; V. NAGAI; N.R. BRAGA; M. DO C.S.S. NOVO; M.B.P. CAMARGO \\ Instituto Agronómico de Campinas-IAC, C.P. 28 - CEP: $13001-970$ - Campinas,SP
}

\begin{abstract}
An experiment to study the growing pattern of a chickpea variety, IAC-Marrocos, was carried out at the Monte Alegre Experimental Station, SP, during 1987 and 1988. The dry matter production of all parts of the plant, as well the leaf area index, were weekly evaluated. Exponential quadratic models of regression were adjusted to total dry matter, leaf dry matter and leaf area index, and a linear model to dry matter of grain. Based on the growth analysis it was concluded that the chickpea is a nustic eatable plant that can be recommended as an alternative winter crop for similar climatic conditions as those of the experiment.
\end{abstract}

Key Words: chickpea, growing indexes, yield

\section{ANÁLISE DE CRESCIMENTO DO GRÃO-DE-BICO}

RSSUMO: Com a finalidade de avaliar o padrão de crescimento do grão-de-bico, variedade IAC-Marrocos, realizouse um experimento na Estaçåo Experimental de Monte Alegre do Sul, SP, nos anos agricolas de 1987 e 1988. Semanalmente eram feitas coletas de plantas e apos a separação das partes, eram obtidos os pesos secos, bem como o ́ndice de área foliar. Esses dados foram analisados com modelos de regressáo linear e exponencial ajustados para as matérias secas de grão, de folha e total e para os indices de área foliar e de crescimento. Baseando-se na analise de crescimento conclui-se que o grăo-de-bico é uma planta que pode ser recomendada como altemativa para a cultura de inverno em condiçzes climáticas semelhantes as do presente estudo.

Deacritores: grāo-de-bico, indices de crescimento, produção

\section{INTRODUCTION}

The chickpea belongs to the Leguminosae family and has been extensively cultivated in South Asia for centuries. It was introduced more recently into Spain and Mexico, that consume this grain in large quantities. Brazil has no comercial production of chickpeas and the greatest amount sold in the local market comes from importation.

Some few trials have shown that some Brazilian regions have good aptness for this crop and so it can be an excellent alternative as winter crop.

The growth analysis is a fundamental technique used to quantify the growth components, represents the first step in the analysis of primary production and is the most practical method for assessing net photosynthetic production. WATSON (1952) reviewed the techniques of growth analysis; RADFORD (1967) presents a review of their formulae, their derivation and conditions for their use and KVET et al. (1971) introduced a new concept that uses curves which are fitted to the data so that they approximate the real growth curve.
The principal objective of growth analysis is to detect if growth and yield are affected by some environmental factor (BISCOE \& WELLINGTON, 1984) or if at one stage of development the crop is more affected by the environment than by another factor (WARREN \& WELLINGTON, 1984). The achieved information with this kind of analysis is useful to project crop schedules.

The purpose of this study was to quantify the production and allocation of dry matter of chickpea, v. IAC-Marrocos, during two consecutive years, in a presumeable well adapted region.

\section{MATERIALS AND METHODS}

The experiment was conducted on a red-yellow podzol at the Monte Alegre do Sul Experimental Station $\left(777 \mathrm{~m}\right.$ above sea level, $46^{\circ}$ $43^{\prime} \mathrm{W}, 22^{\circ} 41^{\prime} \mathrm{S}$ ) during two consecutive years, 1987 and 1988. A corrective manuring was made at a rate of 2 ton/ha of dolomitic lime and $250 \mathrm{~kg} /$ ha of superphosphate drilled with the seeds, which were inoculated with specific Bradyrhizobium spp. 
Sowing took place on 01 April 1987 and 24 April 1988. In both years row spacing was $50 \mathrm{~cm}$ and population was 10 plants $/ \mathrm{m}$.

Sampling started two weeks after sowing and continued at weekly intervals up to commercial maturity, on 19 August 1987 and 23 August 1988. Samples were randomly selected from an uniform area of approximately $0.5 \mathrm{ha}$. At each sampling, five samples of all the plants enclosed in $1 \mathrm{~m}^{2}$ were hand dug.

The plants were separated into leaf lamina, stem, pod and seed and dry weights were recorded. A sample of leaf lamina of each harvesting was used for leaf area determination with the aid of an eletronic planimeter, type LI 3000.

The climatic data (temperature, rainfall and insolation) were obtained from the meteorological station located close to the experimental area.

The method of growth analysis used in this trial involved the calculation of various mean rate changes in plant weights $\left(w_{2}\right.$ and $\left.w_{1}\right)$ and leaf areas $\left(L_{2}\right.$ and $\left.L_{1}\right)$ observed at two sampling periods $\left(t_{2}\right.$ and $\left.t_{1}\right)$ as follows:

Leaf Area Index (L),

$L=L A / P \quad L A=$ leaf area $\quad P=$ land area

Crop Growth Rate (Ct),

$C t=\left(w_{2}-w_{1}\right) /\left(t_{2}-t_{1}\right)$

Relative Growth Rate (Rw)

$R w=\left(\log _{e} w_{2}-\log ^{e} w_{1}\right) /\left(L A_{2}-L A_{1}\right)\left(t_{2}-t_{1}\right)$

Equations were fitted to the data for each variable using models of linear and exponential regression.

\section{RESULTS AND DISCUSSION}

The mean values of temperature, rainfall and insolation during the crop cycle are shown in Figure 1 and are compared with the mean values of the last 30 years in the region.

The regression equations of plant data are shown in TABLE 1.

Flowering took place on 10 June 1987 and 12 July 1988, fixing vegetative periods of 71 and 78 days and reproductiye periods of 70 and 63 days, respectively.

The crop biometric characteristics are represented in Figure 2 and the curves describing the growth indexes in Figure 3.

Sci. agric., Piracicaba, 51(3):430-435, set./dez. 1994
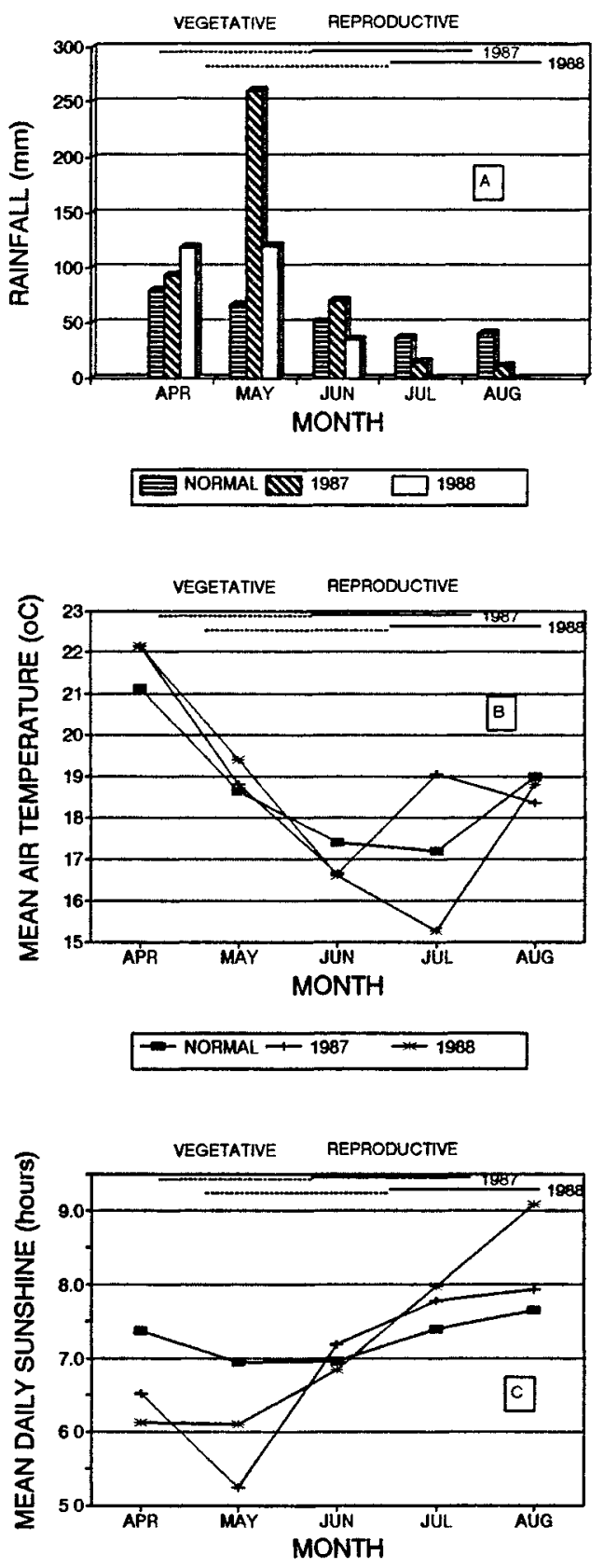

- NORMAL $\leftarrow 1987 \div 1988$

FIGURE 1. Values of rainfall, mean temperature and daily sunshine during the 1988 and 1989 growing seasons of the chickpea crop, cv IAC-Marrocos, compared with the values of the last 30 years in the region. 

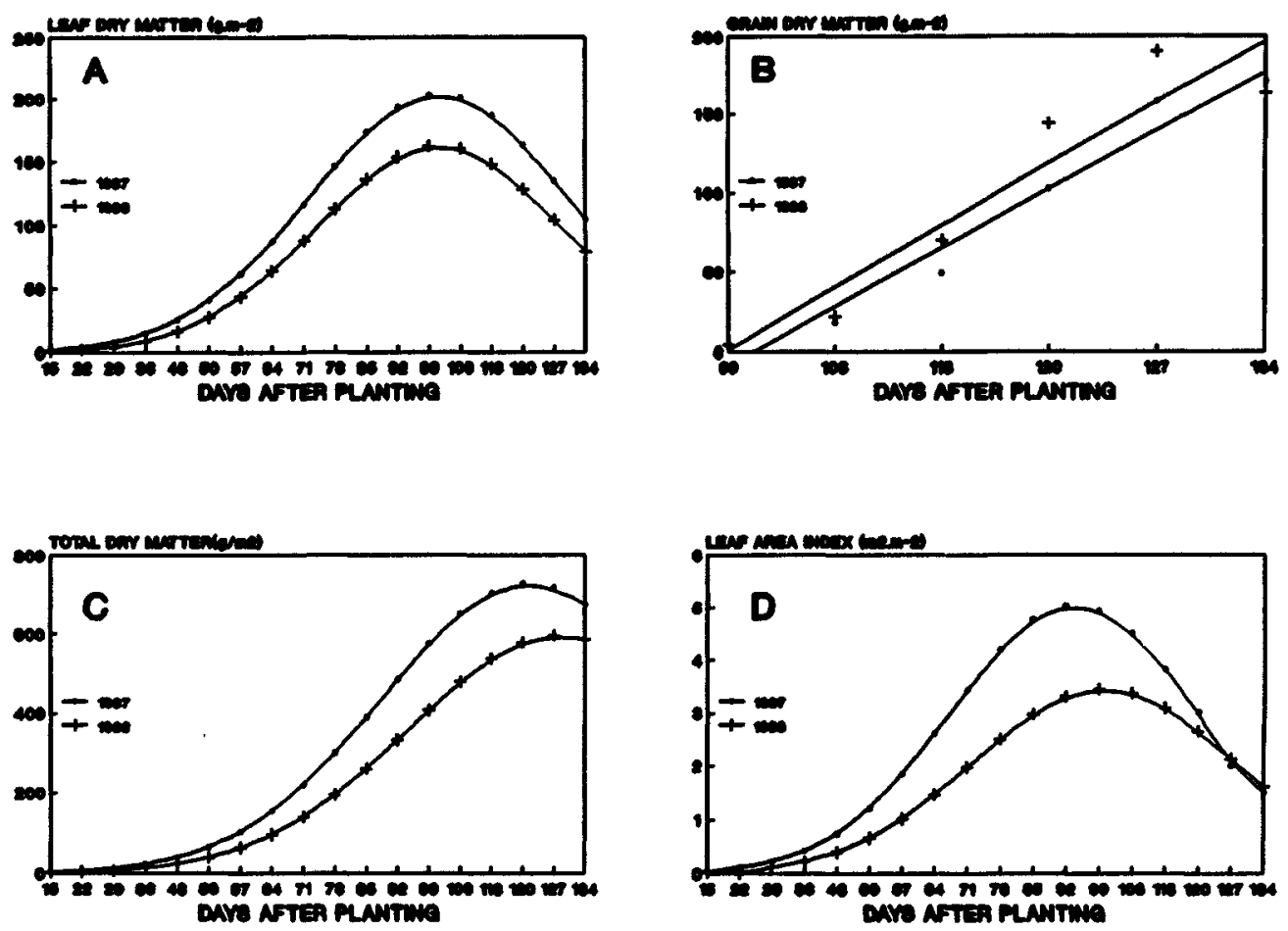

FIGURE 2. Growth parameters of chickpea plant, v. IAC-Marrocos: leaf dry matter (A); grain dry matter (B); total dry matter (C) and leaf area index (D) during the growing seasons of 1987 and 1988.

TABLE 1. Regression equations adjusted to leaf dry matter (LDM), grain dry matter (GDM), total dry matter (TDM) and leaf area index (LAI) and determination coefficients for the chickpea crop, v IAC-Marrocos, during the 1987 and 1988 growing seasons.

\begin{tabular}{|c|c|c|}
\hline \multicolumn{2}{|c|}{ Variables $\mathbf{R}^{2}$} & Equation \\
\hline LDM 87 & 93.93 & $Y=0.3723 . \exp 0.1246 X-0.000616 X^{2}$ \\
\hline LDM 88 & 90.42 & $Y=0.1569 . \exp 0.1388-0.000677 X^{2}$ \\
\hline GDM 87 & 99.74 & $Y=-529.2+5.263 X$ \\
\hline GDM 88 & 95.47 & $Y=-547.2+5.5375 X$ \\
\hline TDM 87 & 97.09 & $Y=0.6691 . \exp 0.1153 X-0.000475 X^{2}$ \\
\hline TDM 88 & 98.04 & $\mathrm{Y}=0.4078 . \exp 0.1135 \mathrm{X}-0.000442 \mathrm{X}^{2}$ \\
\hline LAI 87 & 91.30 & $Y=0.0070 . \exp 0.1405 X-0.000750 X^{2}$ \\
\hline LAI 88 & 82.55 & $Y=0.00045 . \exp 0.13280 X-0.00066 X^{2}$ \\
\hline
\end{tabular}

Leaf dry matter (W) during 1987 and 1988 seasons were adequately described by a quadratic exponential function. In both seasons the maximum value was reached at 100 days, decreasing after this stage because of the assimilate translocation to the grain, the senescence and the leaf fall. In the second year, the photosynthetic apparatus was smaller in the above ground part of the plants. As the variation of temperature in both years was small, it is suposed that the difference is related to the higher rainfall quantity in 1987 during the growing season $(335 \mathrm{~mm})$, in comparison to the second year quantity (112.8 $\mathrm{mm})$. The leaf dry matter continued to increase before flowering (reproductive stage), the values being higher in the first year probably because of the more abundant rainfall during this period ( 85 $\mathrm{mm}$ vs. $0 \mathrm{~mm}$ ). 

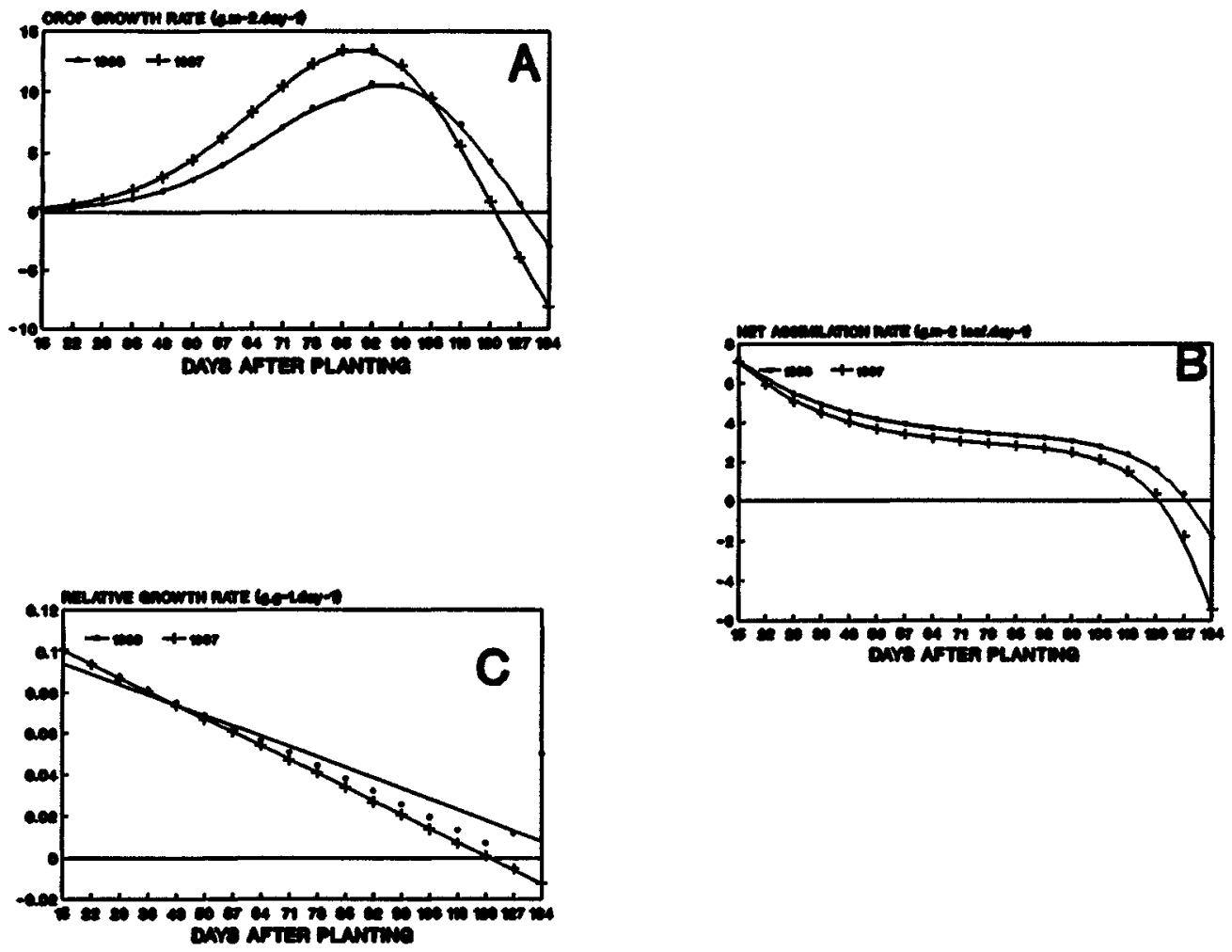

FIGURE 3. Growth indexes of chickpea plant, v. IAC-Marrocos, during the growing seasons of 1987 and 1988: crop growth rate (A); relative growth rate (B) and net assimilation rate (C).

The grain dry matter $(\mathrm{Wg})$ is described by a linear function and is shown in Figure 2-B. The difference of grain amount produced along both years is not considerable although the straight line describing the tendency shows slight superiority in the second year. The yield in both years is similar to that of traditional productive countries (SAXENA \& SHELDRAKE, 1980).

Total aboveground dry matter accumulation (Wt), leaves + stems + pods + grains, was adjusted by a quadratic exponential function. The behavior was similar, shown by the Wt maximum that was reached in the same stage of development, for both years. The value was higher in the first year due the larger amount of dry matter produced by vegetative organs. The reproductive fractions differed slightly.

The leaf area index (L) was described by a quadratic exponential regression equation (Figure
2-D). The maximum value reached in the first year was $45 \%$ higher than in the second.

It is well known that crop photosynthesis depends directly on its photosynthetic apparatus, mainly of its leaf area that intercepts sunlight. BROUGHAM (1956) showed that the percentage of light interception as much as the dry matter production rate increased with the leaf area. However authors disagree about the nature of photosynthetic response to excedent $L$ and the one required to maximum yield. BROUGHAM (1958) fixed as critical $L$ the value that intercepts $95 \%$ of incident sunlight. Therefore it is important to know the basic response of each varity to $L$ maximum an that one with biological and economic meaning (SHIBLES \& WEBER, 1965). HUNT (1978) observed that $L$ is influenced by climatic factors. In 1987 experiment the maximum value reached. seemed to be excessive to grain yield. The better 
hidric conditions of the 1987 experiment provided a larger canopy. Its branched architecture provided shade to lower leaves. These leaves may loose the capacity to sustain a positive carbon balance. SHELDRAKE \& SAXENA (1979) found different $L$ values of the same chickpea variety, at different sites, despite of same growing pattern. They attributed the difference to the climate, specially rainfall.

The crop growth rate $(\mathrm{Ct})$ was higher in 1987 at 90 days, when the grain filling began (Figure 3-A). The values were identical in 1987 and 1988 at about 110 days and were higher in 1988 throughout the ripening stage when values declined due the losses of assimilates.

The behavior of the chickpea crop is different than that of the com (MACHADO et al., 1982), and of soybean crops (BUTTERY, 1974).

In those crops the highest $\mathrm{Ct}$ values agree with the flowering time, since they have determinated growth habits. The highest value obtained in this trial was $14 \mathrm{~g} \cdot \mathrm{m}^{-2}$. day ${ }^{-1}$ in 1987 and $11 \mathrm{~g} \cdot \mathrm{m}^{-2}$. day ${ }^{-1}$ in 1988 . However, the higher index value of 1987 didn't mean that the yield was also higher.

The relative growth rate $(\mathrm{Rw})$ decreased with age in both years due the progressive increase of non assimilatory tissues. In this experiment, as Rw was similar in both years, the fact suggests that environment had no effect in this rate (Figure 3-B).

The net assimilation rate (EA) values obtained in 1988 were slightly higher than in 1987 (Figure 3-C), indicating larger crop efficiency. The EA decreased rapidly until the flowering stage, remaininig stable during grain filling and decreasing rapidly after the $L$ maximum at 100 days. It attained the value zero at 120 days and was negative after this time. It indicated a negative assimilate balance. Being the EA a plant efficience index and being higher in the second year, it is probable that the $L$ in 1987 had exceeded the optimum value for this crop. Another suggestion is that in the second year the insolation was higher (Figure 1-C) and provided a higher photosynthetic rate that provided better grain filling, in addition to the best sunlight improvement due the reduction of self shading. The results of this experiment indicate that the insolation and consequently, the radiation, may have importance for the chickpea crop, justifying further testing.

\section{CONCLUSIONS}

The different values of growth indexes, in the two years of the experiment, showed that the plant growth is more affected by climatic factors than the grain production.

The chickpea plant had good pcrformance and can be recomended as a promising winter crop at similar climatic and soil conditions that of this experiment.

\section{REFERENCES}

BISCOE, P.; WELLINGTON, A. Timing husbandry to crop development. Farm Business, Warwick, p.32-33, 1984.

BRIGGS, G.E.; KIDD, F.A.; WEST,C. A quantitative analysis of plant growth. Annals of Applied Biology, London, v.7, p.202-223, 1920.

BROUGHAM, R.W. Effect of intensity of defoliation on regrowth of pasture. Australian Journal of Agricultural Research, Victoria, v.7, p.377-387, 1956.

BROUGHAM, R.W. Interception of ligth by the foliage of pure and mixed stands of pasture plants. Australian Journal of Agricultural Research, Victoria, v.9, p.39$52,1958$.

BUTTERY, B.R. Analysis of growth of soybean as affected by plant population and fertilizer. Canadian Journal of Ptant Science, Ottawa, v.49, p.675-684, 1974.

HARDWICK, R.C. Some recent development in growth analysis - a review. Annals of Botany, London, v.54, p.807-812, 1984.

HUNT, R. Growth analysis of individual plants. In: ARNOLD, E. (ed) Plant Growth Analysis. Southhampton: Camelot Press. 1978. p.26-28.(Studies in Biology, 6).

KVET, J.; ONDOK, J.P.; NECAS, J.; JARVIS, P.G. Methods of growth analysis. In: SESTAK, $Z$.; CATSKY, J.; JARVIS, P.G. (eds.), Plant Photosynthetic Production: manual and methods. The Hague: The Hague Publisher, 1971. p.343384.

LADIZINSKY, G. The origin of chickpea Cicer arietinum L. Euphytica, Wageningen, v.25, p.211-217, 1976 . 
MACHADO, E.C.; PEREIRA, A.R.; FAHL, J.I.; ARRUDA, H.V.; SILVA, W.T.; TELXEIRA, J.P.F. Análise quantitativa de crescimento de quatro variedades de milho em três densidades. Pesquisa Agropecuária Brasileira, Brasília, v.17, p.825-833, 1982.

RADFORD, P.J. Growth analysis formulae - their use and abuse. Crop Science, Madison, v.7, p.171-175, 1967.

SAXENA, N.P.; SHELDRAKE, A.R. Physiology of growth, development and yield of chickpea in India. In: PROCEEDINGS OF THE INTERNATIONAL WORKSHOP ON CHICKPEA DMPROVEMENT. Hyderabad. 1980. Proceedings... Potanchiru, International Crop Research for Semiarid Tropic. 1980. p.89-90.

SHELDRAKE, A.R.; SAXENA, N.P. The growth and development of chickpeas under progressive moisture stress. In: MUSSEL, H.; STAPLES, R.C. (eds) Stress Physiology in Crop Plants. New York. John Wiley, 1979. p.465-483.
SHIBLES, R.M.; WEBER, C.R. Leaf area, solar radiation interception and dry matter production by soybeans. Crop Science, Madison, v.5, p.575-577, 1965.

THORNE, G.N. Variations with age in net assimilation rate and growth attributes of sugarbeet, potato and barley in a controlled environment. Annals of Botany, London, v.24, p.356-371, 1960.

WARREN WILSON, J. Effects of seasonal variation in radiation and temperature on net assimilation and growth rates in an arid climate. Annals of Botany, London, v.31, p.41-57, 1967.

WATSON, D.J. The physiological basis of variation in yield. Advances in Agronomy, New York, v.4, p.101$145,1952$.

WEST, C.; BRIGGS, G.E.; KIDD, F. Methods and significant relations in the quantitative analysis of plant growth. New Physiologist, Oxford, v.19, p.200-207, 1920 .

Recebido para publicação em 28.03.94

Aceito para publicação em 01.10 .94 